\title{
Analysis of Leadership Style on Performance (Case Study Employee of Directorate of Infrastructure Investment Development, Ministry of Public Works and Housing)
}

\author{
Jeffy Alfanny \\ Magister of Technology Management, Sepuluh Nopember Institute of Technology \\ jeffy alfanny@yahoo.com
}

Diterima: $10-04-2018$

Direview: $16-07-2018$

Diterbitkan: 27-07-2018

Hak Cipta @ 2017 oleh Penulis (dkk) dan Jurnal Sosial Humaniora (JSH)

*This work is licensed under the Creative

Commons Attribution International License (CC BY 4.0).

http://creativecommons.org/licenses/by/4.0/ Open Access

\begin{abstract}
Subject Areas: Leadership, Human Resource Management
Abstract

Leadership is a key element in an organization. The soul of leadership must be owned by every leader who has the main task of managing activities in the organization. This study aims to determine the desired leadership style in the working environment of Directorate of Infrastructure Investment Development (DBII), Ministry of Public Works and Housing. This research uses a quantitative approach using survey method, priority-scale approach, regression analysis and focus group discussion (FGD). The results showed that there were at least 3 (three) leadership styles commonly used by leaders namely, authoritarian, delegative and participatory styles. Based on the survey and FGD results, participative leadership style is the preferred style of leadership in the work environment of the Directorate of Infrastructure Investment Development while the regression results show that the leadership style of participatory has a positive influence with performance. Participative leadership style can be implemented in leadership development activities in the working environment of Directorate of Infrastructure Investment Development but still needed coordination and agreement from the internal party and related external institution having capacity and competence in human resource development.
\end{abstract}

Keywords: Authoritarian; Delegative; Participative Leadership Style; Performance.

\section{Introduction}

The Directorate of Infrastructure Investment Development (DBII) is a government agency under the Ministry of Public Works and Housing which is implementing bureaucratic reform through a performance-based budgeting structure. But for about three years from 2013 to 2016, the average budget absorption in DBII is only around $89 \%$. This shows that there are obstacles to the realization of the budget in which the performance of employees becomes a major factor in influencing the condition.
As described in Article 7 paragraph (2) of Government Regulation no. Law No. 21 of 2004 on Preparation of Work Plan and State Budget/institution states that the performance-based budget structure itself refers to the three components of the formula namely, performance indicators, cost standard analysis and performance evaluation where the first and last components showed employee performance involvement in the process of budget realization.

The performance of an employee cannot be separated from the leadership of a leader. Good leadership is able to motivate, and coordinate individuals to achieve 
optimal performance of organizational goals. Looking at the problematics above the author tries to examine the condition of performance that is not optimal whether it is influenced by leadership style of a leader and what kind of leadership style is suitable to answer that.

\section{Literature Review}

Koontz, O'Donnell, and Weihrich (1990: 147) mentioned that leadership is the influence, art or process of influencing people so that they will strive to achieve group goals with will and enthusiasm. Every leader has a different style of leadership with one another, not always a leadership style better or worse than other leadership styles because the situation or working climate come into play here. Leadership styles can be defined as behavioral behaviors designed to integrate organizational goals with individual goals to achieve a particular goal, Ranupandojo (1986:24). Hasibuan (2000: 168) mentions at least three kinds of leadership styles commonly used by leaders, namely, authoritarian, delegative and participatory styles.

According to Robbins and Coulter (2002) states, authoritarian leadership styles describe leaders who tend to focus power on themselves, dictate how tasks must be completed, make decisions unilaterally, and minimize employee participation. Authoritarian leadership styles embrace a closed management system. The characteristics or indicators of authoritarian leadership according to Sutikno (2007, 21) are Command, Supervision, and Pressure.

The style of delegation leadership is characterized by the rarity of leaders providing direction, decisions submitted to subordinates, and expected members of the organization to solve its own problems (MacGrefor, 2004). The leader will not make rules about the execution of those jobs and only make little contact with his subordinates. In this case, subordinates are required to have maturity in work (ability) and psychological maturity (willingness). The following is a feature or indicator of the delegative leadership style are a delegation of authority, Trust, and Initiative. Mitch McCrimmon (2007) writes that being a participative leader means involving team members in decision making. This is especially important when creative thinking is needed to solve complex problems or make decisions that will impact team members. Koontz, O'Donnell, and Weihrich (1990: 163) mentioned the participative leadership style emphasizing on three leadership approaches such as directive leadership, supportive leadership, leadership initiative.

According to Dharma (1986: 32) Performance is something done or product/service produced or given a person or group of people. Some experts interpret the word performance is derived from the word job performance or actual performance is the performance of work or achievement actually achieved by someone. Furthermore, Mangkunegara (2002: 67) describes the performance is the work of quality and quantity achieved by an employee or employee in performing their duties in accordance with the responsibilities given to him. Koontz, O'Donnell, and Weihrich (1990: 147) explain the relationship between leadership style and performance is motivation. Motivation becomes one of the elements of leadership. The essence of leadership is a followership, in other words, that the desire of the people to follow will make a person a leader. So an effective leadership style raises the motivation for subordinates to maximize their performance. Based on a literature review, a hypothesis is obtained :

1. Based on 3 (three) leadership styles namely, authoritarian, delegative and participative. 
there is one leadership style desired by subordinates in DBII.

2. The leadership style desired by subordinates has a positive influence on performance.

3. The leadership style desired by the subordinate can be implemented in leadership coaching in the work environment of DBII.

\section{Method}

\section{a. Research Design and analysis}

The study is based on cross-sectional survey research design as no variables examined are manipulated. The priority-scale approach based on the characteristics possessed by the three leadership styles. The predictor variables are leadership style, subordinate relationship, and job performance. The data are analyzed using the Statistical Package for Social Sciences. Specifically, stepwise multiple regression analysis is subordinate to test the strength of the leadership style variables on job performance.

\section{a. Participant}

This research is focused on the research of subordinate population in DBII hence in this research, it is determined that the respondents to be studied are 58 staffs of DBII.

\section{b. Instrument}

A structured questionnaire is used to collect relevant information from the participants in the study. The questionnaire contains information such as age, educational level, work experience, leadership style and job performance.

In the determination of priority scale, 3 indicators are taken based on their individual characteristics - each style of leadership. Then from the 9 indicators, respondents were asked to give the order of which indicator is considered as a priority to less priority. The first selected indicator will be multiplied by 9 points, the second selected indicator will also be multiplied by 9 points and so on. In the end, the percentage of priority weight will be calculated. Then, after leadership style is obtained, that has the largest percentage or desired by the majority of respondents then the research will be continued by performing statistical tests of the desired leadership variables to find out whether there is any correlation with the performance variables.

Data obtained from the distribution of the questionnaires will then be processed and analyzed by the following method:

- Qualitative analysis is an analysis that does not use mathematical models, statistics or certain other models. Qualitative analysis in this research is sorting scale priorities and Focus Group Discussion (FGD)

- Quantitative analysis is a data analysis performed by way of classifying, comparing, and calculating the numbers with the relevant formulas. Quantitative analysis is used to test the validity and reliability of the classical assumption test, $\mathrm{F}$ test, T-test, and multiple linear regression test. 
Figure 1

The Picture of the Flow Research Method

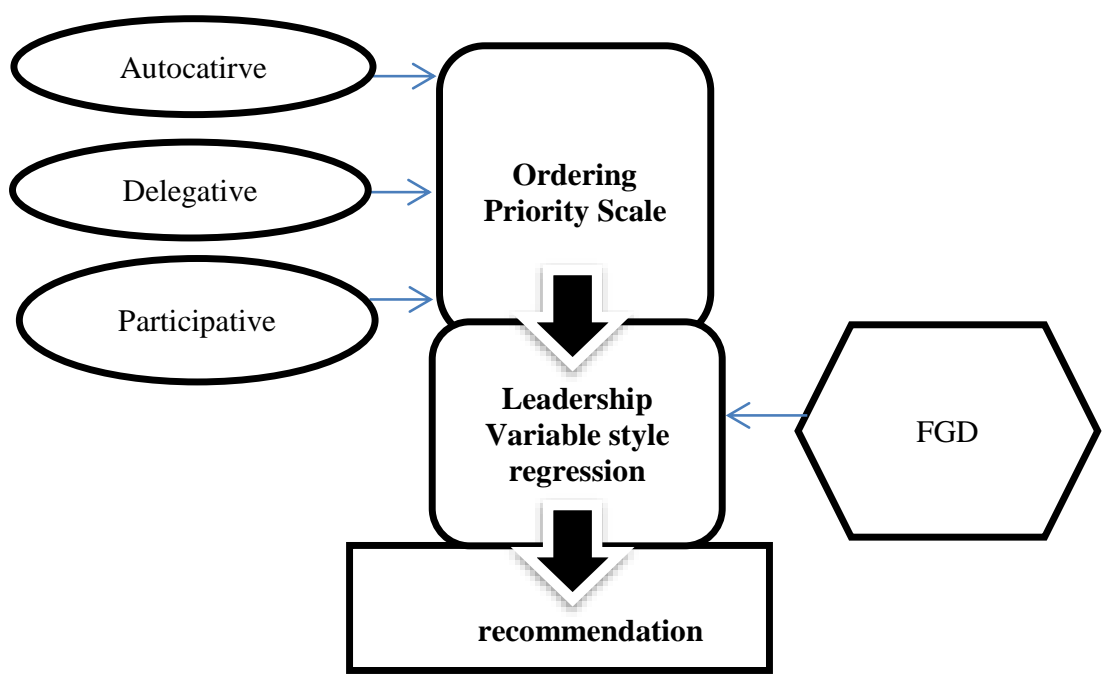

When the leadership style has been obtained that has been in accordance with the staff desired in DBII then the leadership style will be processed again to look for which variables have the most dominant influence. After the results obtained then the results will be continued to FGD to obtain a recommendation on this research and recommendations for the agency under investigation.

\section{Result}

Respondents indicated that they consist of $60 \%$ of bachelor's education degree, $14 \%$ of Masters degree, $10 \%$ of diploma degree and $16 \%$ of Senior High School. Besides that most respondents have work experience 6 - 10 years equal to $67 \%$, work experience 1 - 5 year equal to $31 \%$ and work experience 11 - 15 year equal to $2 \%$ and most respondents were in their thirties annual age is $78 \%$, forty-year age is $12 \%$ and twenty annual age is $10 \%$. This shows that the respondents have a good level of maturity and caution in answering all the questions in the questionnaire.

\section{a. Priority Scale Result}

Based on the priorities that have been sorted and calculated from the size of the weight of the sorting points, it is then obtained a percentage of leadership style selection in table 1 :

Table 1

Indicator Ranking Table

\begin{tabular}{|c|c|c|c|c|}
\hline Leadership Indicator & $\begin{array}{l}\text { Percent } \\
\text { age }\end{array}$ & Leadership & Percentage & Rank \\
\hline The Absolute Decision & 8,6 & \multirow[t]{3}{*}{ Authoritarian } & \multirow{3}{*}{29,32461874} & \multirow{3}{*}{2} \\
\hline strict supervision & 7,8 & & & \\
\hline Detailing Subordinate Duties & 12,8 & & & \\
\hline Not Motivating Subordinates & 5,4 & \multirow[t]{3}{*}{ Delegative } & \multirow{3}{*}{24,70588235} & \multirow{3}{*}{3} \\
\hline Submit full responsibility & 8,4 & & & \\
\hline Task directives as necessary & 10,8 & & & \\
\hline positive organizational climate & 16,7 & \multirow[t]{3}{*}{ Participatory } & \multirow{3}{*}{45,96949891} & \multirow{3}{*}{1} \\
\hline Guidelines for the task & 14,6 & & & \\
\hline Decision-making opportunities & 14,5 & & & \\
\hline
\end{tabular}


It is known that in the priority sequencing that the chosen respondent is led by authoritarian leadership style of $29.3 \%$ while the chosen respondent is led by a delegative leadership style of $24.7 \%$ and the respondent chooses to be led by a participative leadership style of $45.9 \%$. This means that most respondents want to be led by a participative leadership style. Thus the investigation will be followed up by analyzing the relationship of participative leadership style with performance.

\section{a. Regression Result}

Koontz, O'Donnell, and Weihrich (1990: 163) show that participatory leadership style emphasizes on three approaches/indicators, namely: directive leadership, supportive leadership, leadership initiative. There is a mindset between participative leadership style and performance in picture 2 :

Figure 2

Plot of Participative Leadership Style and Performance

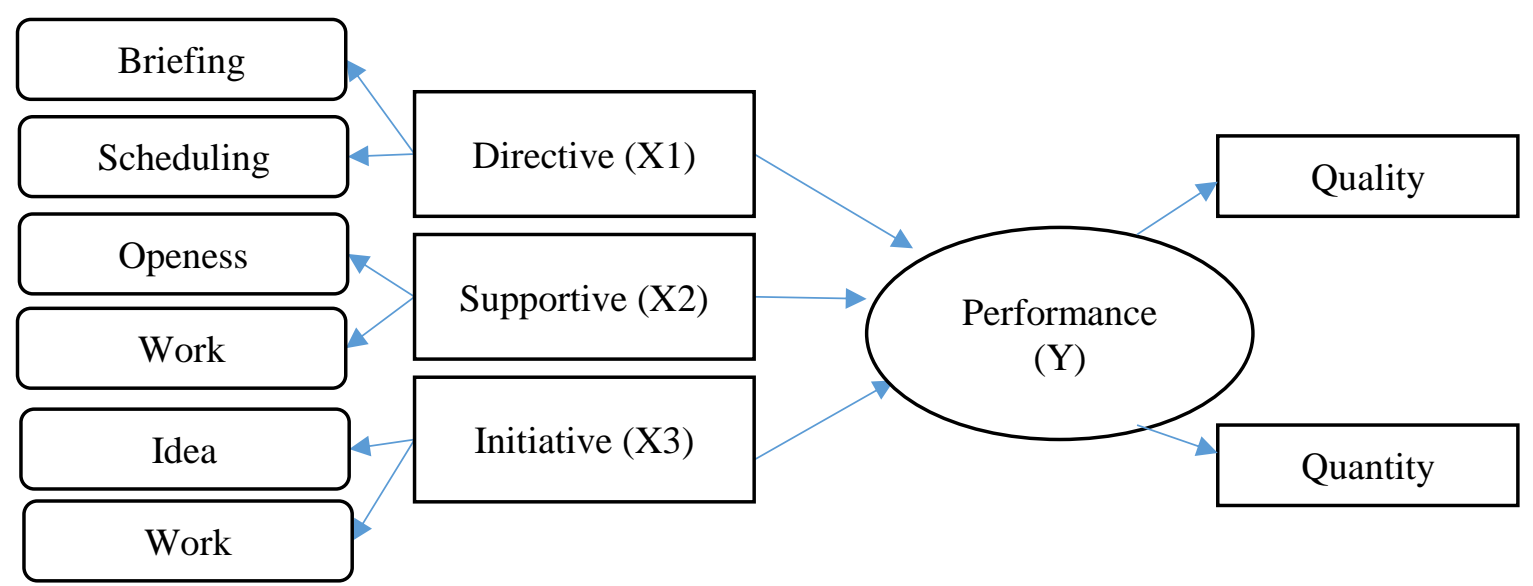

Note: Indicator Independent Variable Dependent Variable Indicato

From the picture of the relationship between dependent variable and independent variables above, the obtained formulation of a regression equation that will be calculated by using linear regression analysis is as follows:

$$
\begin{gathered}
\text { Performace }(\mathrm{Y})=\text { Directive }(\mathrm{X} 1)+\text { Supportive } \\
(\mathrm{X} 2)+\text { Initiative }(\mathrm{X} 3)+\mathrm{e}
\end{gathered}
$$

Multiple linear regression calculation is used to predict the relation between the dependent variable of employee performance (Y), with the independent variable of participative leadership (X). The results of multiple linear regression can be seen in table 2:

Table 2

Regression Analysis Table Result

\begin{tabular}{|l|l|c|c|c|c|l|}
\hline \multirow{2}{*}{ Variabel } & \multicolumn{2}{|c|}{ Unstandardized Coefficients } & $\begin{array}{c}\text { Standardized } \\
\text { Coefficients }\end{array}$ & \multirow{2}{*}{ thitung } & Sig. & Keterangan \\
\cline { 2 - 5 } & $\mathrm{B}$ & $\mathrm{Se}$ & $\mathrm{Beta}$ & \\
\hline
\end{tabular}




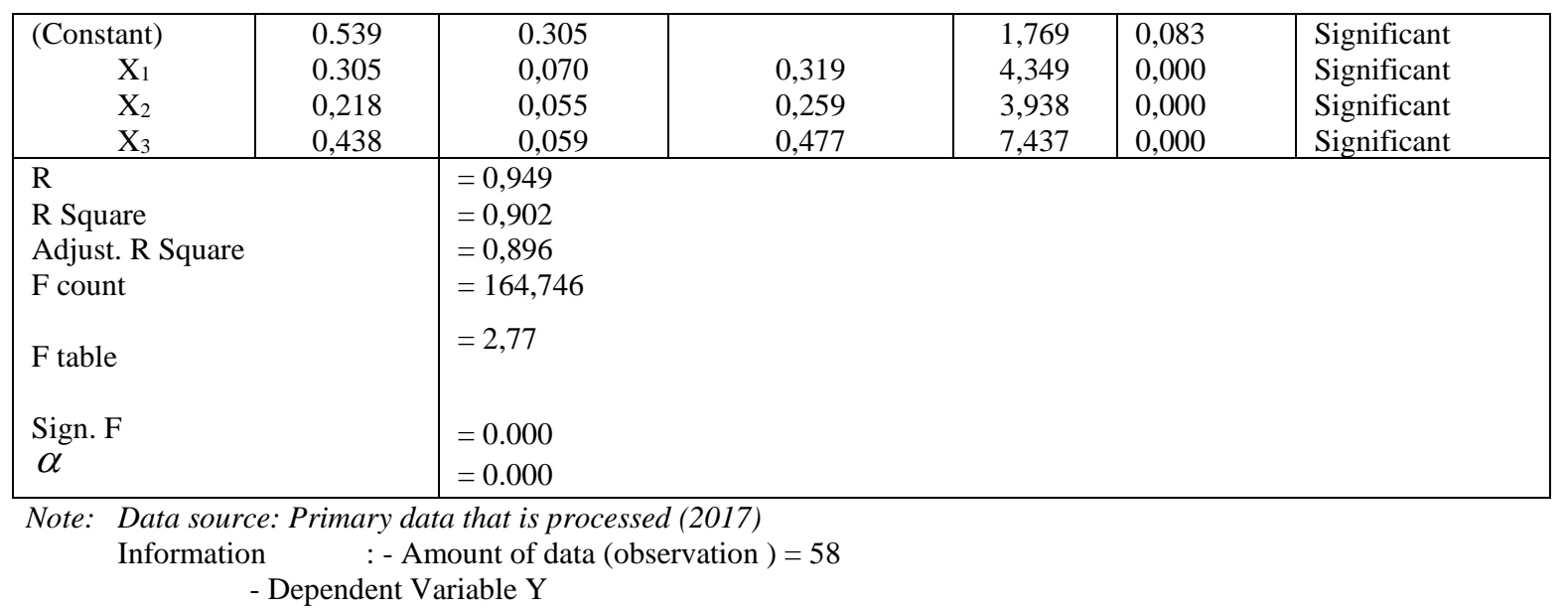

From the data processing obtained the following equations, Dajan (1994: 325):

$Y=0,305 X_{1}+0,218 X_{2}+0,438 X_{3}+0,539$

The value of Adjusted R Square (0.896) shows that the regression model shows a high degree in representing observation. This means that the independent variables directive (X1), supportive (X2), and initiative (X3) are able to explain the change in a dependent variable (Y) by $89.6 \%$. The remaining $10.4 \%$ is explained by independent variables outside the regression equation. The significance value of $\mathrm{F}(0.000)$ is smaller than the significance value $\alpha$ (0.05). So statistically, all independent variables directive (X1), supportive (X2), and initiative (X3) simultaneously have a significant effect on an employee performance dependent variable (Y).

Results $\mathrm{t}$ arithmetic variable directive (X1) 4.349> $1.673 \mathrm{t}$ table with a significance value of 0.000. Supportive variable (X2) 3,938> 2,004 t table with significance value 0,000 . Initiative variable (X3) 7,437> 2,397 t table with significance value 0,000 . The $t$ value of each independent variable $(X 1, X 2$, $\mathrm{X} 3$ ) is greater than the value of table and the significance value of each independent variable is smaller than the significance value $\alpha(0.05)$. So statistically, the variables directive (X1), supportive
(X2), initiative (X3) partially have a significant influence on employee performance (Y). Meanwhile, the initiative variable (X3) has the highest standardized coefficient beta value (0.477). This means the initiative variable (X3) has the most dominant influence on employee performance $(\mathrm{Y})$. All independent variables have a positive relationship direction or the nature of direct relationship so that can be explained if the higher the initiative (X3) the higher the employee's performance (Y), the higher the supportive (X2) the higher the employee's performance $(\mathrm{Y})$, the higher the directive (X1) the higher the employee's performance (Y) assuming other influencing variables are considered fixed (ceterisparibus)

\section{b. Focus Group Discussion Result}

Based on the results of data processing research and discussion activities in the FGD, the following conclusions are obtained :

1. The style of leadership can be learned and mastered so that a person's leadership style is not absolutely applicable to the individual 
because situational conditions can affect a person to adjust his leadership style. Leadership

2. the style is dynamic so that leadership training activities can be made.

3. Participative leadership style can be implemented in the DBII work environment in the form of leadership development activities. However, internal coordination and agreement are still needed, coordination with external or related institutions that have capacity and competence in the field of human resources development is needed, especially to enhance leadership substance so that the research result is really effective on target.

\section{Conclusion and Recommendation}

This study found that there are at least three leadership styles that are often used in organizing, there are authoritarian style, delegative style, and participative style. Among the three styles, the participative leadership style became the number one leadership style desired by the subordinates in DBII followed by authoritarian style as the second most desired leadership style and the delegative leadership style as the least desirable one. The style of participative leadership shows a positive influence on the performance in which the initiative variable becomes the most dominant variable in influencing performance.

The guidance of participative, authoritarian and delegative leadership styles is very likely to be applied in leadership coaching systems in DBII environments. However, cooperation between DBII and related institutions with capacity and capability in human resource development such as the Bureau of Personnel of the Secretariat General, the
BPKSDM of the Ministry of Public Works and Housing, and the State Personnel Board in preparing the guidance of this leadership style is highly needed.

\section{Bibliografi}

Arikunto, Suharsimi. 1996. Prosedur Penelitian Suatu Pendekatan Praktek. Edisi Kedua. Rineka Cipta. Jakarta.

Dajan, Anto. 1994. Pengantar Metode Statistik. jilid II. LP3S. Jakarta.

Djarwanto dan Subagyo Pangestu. 1996. Statistik Induktif II. BPFE. Yogyakarta.

Flippo, Edwin B. 1995. Manajemen Personalia. jilid II. Penerbit Erlangga. Jakarta

Gaspersz, Vincent. 1998. Manajemen Produktivitas Total, Cetakan Pertama, Penerbit PT. Gramedia Pustaka Utama. Jakarta.

Gao - Razak, Malaysia.(2013). "A Multiple Regression Analysis on Influencing Factors of Urban Services Growth in China". Scientific Research, $\underline{4}, 1-5$

Gibson, Invancevivich dan Donnely. 1992. Organisasi dan Manajemen, Perilaku Struktur Proses. Penerbit Erlangga. Jakarta

Gopal - Chowdhury, India. (2014). "Leadership Styles And Employee Motivation: An Empirical Investigation In A Leading Oil Company In India" IMPACT: International Journal of Research in Business Management, 2 (5), 1-10.

Handoko, T Hani. 2000. Manajemen Personalia dan Sumber Daya Manusia. BPFE. Yogyakarta.

Hasan, Iqbal, 2002. Pokok-Pokok Materi Metodologi Penelitian. Ghalia. Jakarta.

Hasibuan, Malayu. 2002. Manajemen Sumber Daya Manusia (Edisi Revisi). Bumi Aksara. Jakarta.

Iqbal - Anwar - Haider, KSA, (2015). "Effect of Leadership Style on Employee Performance". Arabian Journal of Business and Management Review, $\underline{5}$ (5).

Jackson, John H, Mathis, Robert L. 2002. Manajemen Sumber Daya Manusia. Salemba Empat. Jakarta.

Jaroslav, Belás, Slovakia, (2013). "The Leadership Style and the Productiveness of Employees in the Banking Sector in Slovakia". Journal of Competitiveness, $\underline{5}$ (1), 39-52. 
Kartono, Kartini, 1994. Pemimpin Dan Kepemimpinan, Edisi Baru, Penerbit PT. Raja Grafindo Perkasa. Jakarta.

Koontz, O’Donnell, Weihrich. 1990. Manajemen Jilid 1. Edisi Kedelapan, Penerbit Erlangga. Jakarta

.Koontz, O’Donnell, Weihrich. 1990. Manajemen Jilid 2. Edisi Kedelapan, Penerbit Erlangga. Jakarta

Mangkuriprawira, Sjafrfi. 2002. Manajemen Sumber Daya Manusia Strategik. Ghalia Indonesia. Jakarta.

Mangkunegara, Anwar, P. 2005. Manajemen Sumber Daya Manusia Perusahaan. PT Remaja Rosdakarya Offset. Bandung.

Mazlina - Tahir, Malaysia. (2009). "Applying Multiple Linear Regression and Neural Network to Predict Bank Performance". International Business Research, $\underline{2}$ (4)

Mishra - Min, USA. ( 2010).“ Analyzing The Relationship Between Dependent And Independent Variables In Marketing: A Comparison Of Multiple Regression With Path Analysis". Inovative Marketing, $\underline{6}$.

Mulyadi, Deddy. 2015. Perilaku Organisasi dan Kepemimpinan Pelayanan. PT Alfabeta. Bandung.

Nazir, Moh. 1983. Metode Penelitian. Ghalia Indonesia. Jakarta.

Noor, Juliansyah. 2014. Analisis Data Penelitian Ekonomi \& Manajemen. PT. Gramedia Widiasaranan. Jakarta.

Pedro -. Isabel. RDS, Portugal. (2008). "Using Subsystem Linear Regression Metamodels In Stochastic Simulation" European Journal of Operational Research.

Robbins, Stephen P. 2006. Perilaku Organisasi. PT. INDEKS Kelompok Gramedia. Jakarta.

Siagian, Sondang P. 1999 Teori Dan Praktek Kepemimpinan, Cetakan Keempat, Penerbit PT. Rineka Cipta, Jakarta.

Soeprihanto, J. 2000. Manajemen Personalia. BPFE. Yogyakarta.

Simamora, Henry. 2004. Manajemen Sumber Daya Manusia. Edisi ketiga. STIE YKPN. Yogyakarta.

Singarimbun, Masri dan Effendi Sofian (ed). 1995. Metodologi Penelitian Survei. LP3ES. Jakarta.

Sugiyono. 2001. Statistika Untuk Penelitian. Cetakan PertamaKencana Prenada Media Grup. Jakarta.

Sutrisno, Edy, 2009. Manajemen Sumber Daya Manusia. Cetakan Pertama, Penerbit CV. Rajawali, Jakarta 